Copyright (C) 2021 The Author/s

This work is licensed under a CC-BY 3.0 License

Peer review method: Double-Blind

Accepted: September 03, 2021

Published: September 21, 2021

Review article

DOI: https://doi.org/10.47305/JLIA2137373I

\title{
CHINA'S BELT AND ROAD INITIATIVE AND GEORGIA: A SHORT OVERVIEW
}

\author{
Ekaterine Lomia \\ Caucasus International University - Tbilisi, Georgia \\ ORCID iD: https://orcid.org/0000-0002-3525-6730 \\ ekaterine.lomia@ciu.edu.ge
}

\begin{abstract}
Since the beginning of the 2000s, China has embarked on an unprecedented path of economic development, as evidence of which is the largest economic project of the XXI century initiated by the People's Republic of China. The global Belt and Road Initiative announced by the first person of the country, Xi Jinping, is a shortened name of the 'Silk Road Economic Belt' and 'XXI Century Maritime Silk Road'. It covers the Asia-Pacific, Europe, Central Asia, Southeast Asia, West Asia, and Africa and involves more than a hundred countries, international organizations, and leading economic actors. The main participants in the project are China, Mongolia, Russia, Azerbaijan, Belarus, Poland, Germany, the Netherlands, Kazakhstan, Kyrgyzstan, Pakistan, Bangladesh, Iran, and India. The article reviews the role of the Chinese project in a global context. The paper focuses on the role and purpose of Georgia in the Belt and Road Initiative. This study will try to reveal the results for the benefit of Georgia, which is one of the participating countries, and the role of China through research to be made from documents and academic studies on the subject. Georgia tries to conduct its relations with China, as a partner in the project, with a policy of balance without disturbing its relations with the West.
\end{abstract}

Keywords: China; Economy; Belt and Road Initiative; Georgia; US

\section{INTRODUCTION}

At the outset, it is important to note that the term 'Silk Road' belongs to the famous XIX century German scientist, Ferdinand von Richthofen, who first used the word in his work in 1877. From 1868 to 1872 , Richthofen traveled to China seven times and made significant contributions to the study of Chinese culture and tradition (Embassy of the Federal Republic of Germany 2015, 4). However, historically, the earliest stages of the ancient 'Great Silk Road' date back to the II century BC. It was a transcontinental trade-caravan route that connected ancient China to the Western civilization. In 130 AD., during the reign of Emperor Wu of the Khan dynasty, the 'Silk Road' reached its zenith of development. High-quality Chinese silk (and not only silk) was very popular in Byzantium and Parthia (Sasanian Iran) (Mark 2021). 
To control the section of the 'Silk Road' which ran through the Middle East, there were severe conflicts between Byzantium and Parthia, involving Arabs from the VII century and later the Mongols as well (Szostak 2021, 1) (Image 1).

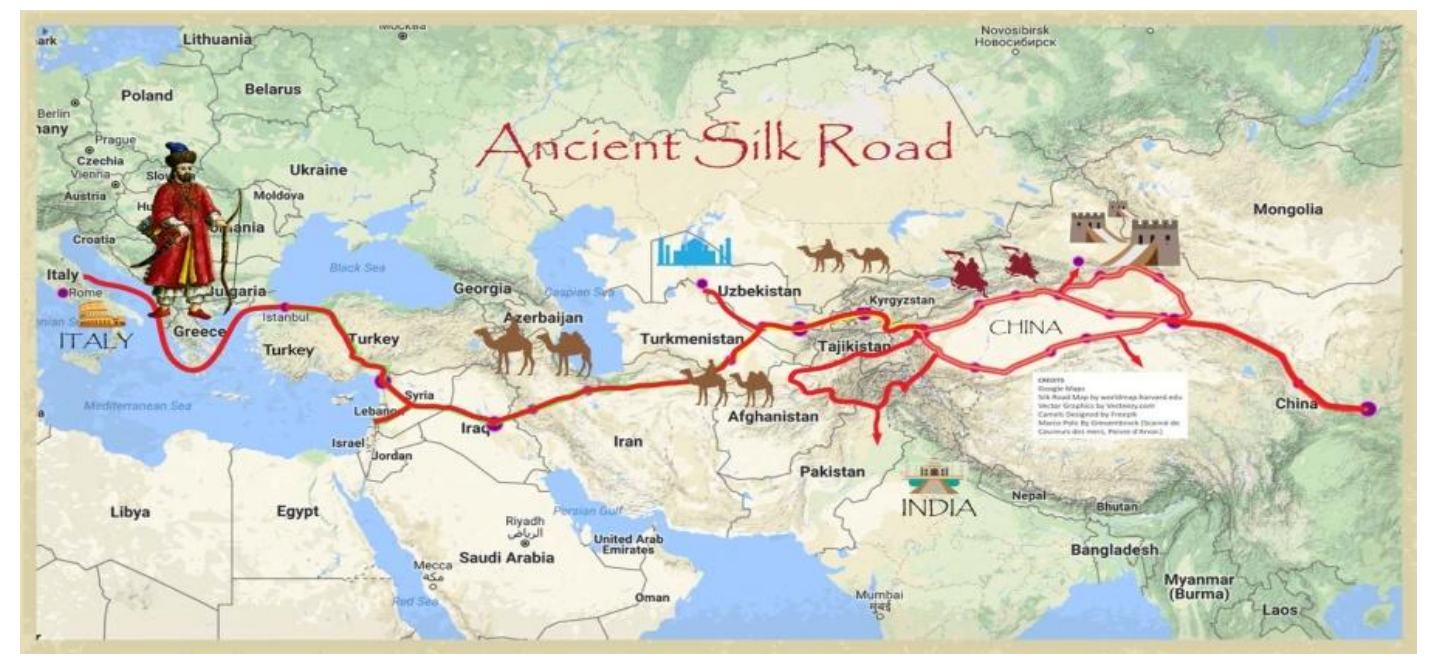

Image 1: Ancient Silk Road Map (Source: Amazing Iran 2021)

From 1453, after the Ottomans conquered Eastern Rome (Byzantine Empire) as a consequence of which the 'Silk Road' gradually lost its significance (Pears 1886, 13). The strong wave of changes in the late Middle Ages further reduced the urgency of the 'Silk Road'. One of the biggest epochs in the history of mankind, known as the 'Great Geographical Discovery' began when the Europeans (primarily the Portuguese and the Spaniards) explored new ocean routes bypassing Africa. A product of these events was colonialism.

At the end of the XIX century and the beginning of the XX century, several projects were proposed by the world's leading players to rebuild the 'Silk Road' over again. In these projects Georgia, along with its natural neighbor Azerbaijan, was undoubtedly perceived. Europe-Caucasus-Asia (TRACECA) Transport Corridor, initiated by the EU in 1993 (TRACECA 2019-2020); INOGATE - initiated by the US Legislature in 1999 (INOGATE 2020) and the US Silk Road Strategy Act - approved by the US in 2011 are clear examples of the mentioned (Vekua 2018, 3-4). However, the most effective is the initiative proposed by the President of China, which radically changes the economic balance of power on the Eurasian continent. Obviously, in the new geopolitical reality, parts of the changes are occurring in the South Caucasus region and, consequently, in Georgia as well. 


\section{THE GLOBAL SIGNIFICANCE OF THE BELT AND ROAD INITIATIVE IN BRIEF}

Xi Jinping's global initiative is a clear example that China eventually deviated from the foreign policy course of Deng Xiaoping, one of the most prominent figures in the country's history, and the initiator of a series of grand reforms, who saw isolation as a key condition for the country's long-term development. In his view, China should have been less involved in 'risky affairs' and should have only focused on strengthening domestic statehood. While there has been controversy in analytical circles over the dimension of the Belt and Road Initiative - economically or geopolitically, Xi Jinping has already been awarded the title of 'Prominent Chinese Leader', along with Mao Zedong, and Deng Xiaoping (Mamradze 2017).

The Belt and Road Initiative, which many scholars even call the 'Marshall Plan of China', aims to create stable zones between the West and the East, develop economic and cultural relations, and establish a new strategy of the balance of power on the Eurasian continent, which is fundamental to peace and prosperity in Eurasia (Sarker, Hossin, and Yin 2018, 623-638). The project has a real opportunity to drastically "change the global economic landscape. It is becoming a major exporter of technology, a World Trade Center, and a major hub for central e-commerce" (Aroshidze 2018, 37). The main directions of the economic zone are:

- North (China-Central Asia-Russia-Europe) - up to the Baltic Sea.

- Central (China-Central and West Asia-Persian Gulf-Mediterranean).

- South (China-Southeast Asia-South Asia-Indian Ocean).

- From Chinese ports - across the South China Sea to the South Pacific.

- From Chinese ports - across the South China Sea to the Indian Ocean. From the Indian Ocean to Europe (Aroshidze 2018, 37) (Image 2).

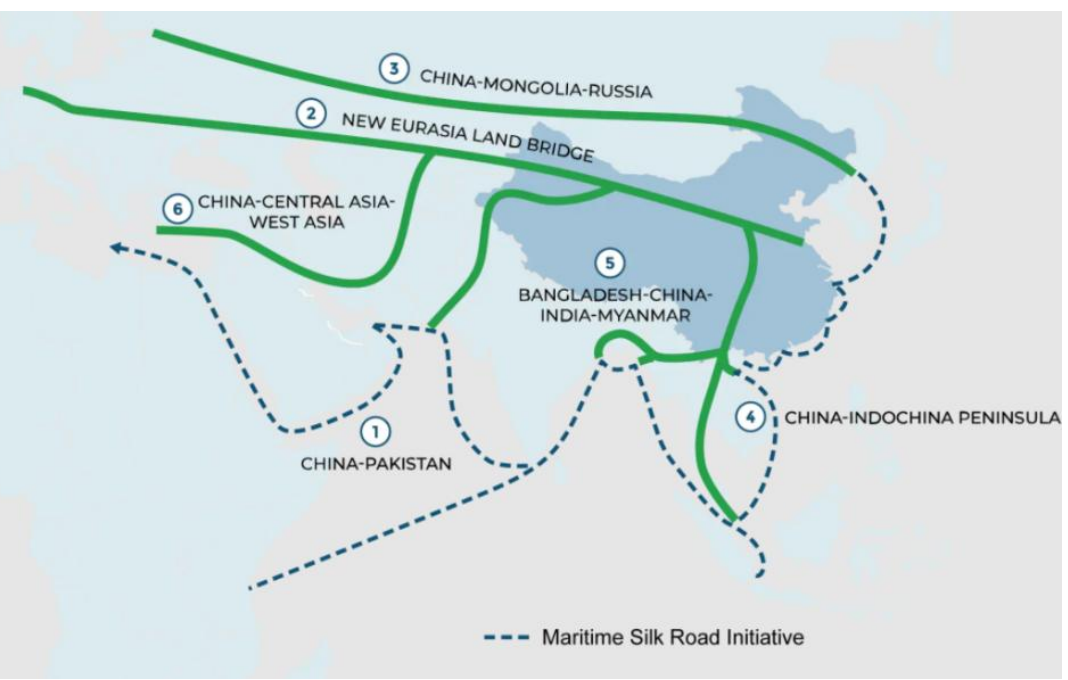

Image 2: Corridors of Power (Source: Standard Chartered 2021) 
From the beginning, the 'Silk Road Economic Belt' project had six main directions. These are the New Eurasian Land Bridge, the China-Mongolia-Russia Economic Corridor, the 'Central Asia-West Asia Economic Corridor', the Indochina Economic Corridor, the China-Pakistan Economic Corridor, and the Bangladesh-China Economic Corridor (Papava 2017, 4). Among them, the Georgia-Azerbaijan section (Caucasus Tandem) is represented in the 'Central Asia-West Asia Economic Corridor'. On the other hand, a visible example of a strategic partnership and cooperation between Georgia and Azerbaijan is the 826-kilometer Baku-Tbilisi-Kars railway, which was officially opened on 30 October 2017. It has great geopolitical significance and plays an important role in the functioning of the Belt and Road Initiative (Chitadze 2021). Not only it connects the countries directly involved in the project but also ensures the shipment of cargo from Asia to Europe. It is estimated that by 2034, 17 million tons of cargo will also be possible to be transported by rail. It is not accidental that in the scientific circles the 'Baku-TbilisiKars' railway is also referred to as the 'Iron Silk Road' (Papava 2008, 47).

If we compare the 'Europe-Caucasus-Asia' (TRACECA) transport corridor with the 'Silk Road Economic Belt' - 'Central Asia-West Asia Economic Corridor', we see that there are some fundamental differences between those projects (TRACECA 2019-2020). In addition to the fact that the 'Europe-Caucasus-Asia' project was initiated by the West in particular, by the European Union, and the 'Central Asia-West Asia Economic Corridor' by the East - in particular, by China, it is clear that the first project is designed for transporting goods and the second is more multifunctional and combines many other areas as well. In the early 2000s, there was a widespread belief in scientific and academic circles that Georgia's function as a transit country would eventually "grow into a complex economic project, contributing to the development of various sectors of the economy" (Papava 2017).

Russian Federation, which was initially considered one of the biggest threats to the project, became a real challenge to the way of implementing the 'Silk Road Economic Belt' project ('Central Asia-West Asia Economic Corridor'). The different visions and interests related to security issues should also be highlighted. For instance, China and Japan are perceived as rivals in the economic context whilst the involvement of India in the project is hampered by the Kashmir conflict. Another impediment to the implementation of the Silk Road is terrorism which itself "poses a threat to human rights, which include the fundamental right to life" (Kiknadze 2007, 51) and remains one of the major problems in the modern world and the most important challenge of international security (Maisaia and Khanjaliashvili 2020, 116; Maisaia 2005, 147). The United States is one of the project's most vocal opponents, whose foreign security strategy names China, Russia, and Iran as its main rivals, while official Beijing, Moscow, and Tehran, in turn, widely spread anti-American narratives and demonize Western institutions. 
In response to the Belt and Road Initiative, Russia launched a new project in 2016 - 'Greater Eurasian Partnership' as a continuation of the Eurasian Economic Union. If the Eurasian Economic Union consists of Russia, Kazakhstan, Kyrgyzstan, Tajikistan, Armenia, and Belarus, the Greater Eurasian Partnership is a far-reaching and ambitious unification of nations which along the abovementioned countries includes China, India, Iran, and Turkey (Nurgaliyeva 2016, 93-96). From Russia's point of view, such a configuration of countries is a vital task in "balancing the threats posed by the United States and its allies" (Karaganov 2016). From Russia's perspective, the Great Eurasian Partnership is not only an economic project of global significance, but it also has a deep geopolitical and ideological character, as Russia has always played a major role in dominating the Eurasian continent. In his book 'American Strategy in World Politics', the author Nicholas J. Spykman argued that Eurasia, including the Bering Sea from the Baltic Sea onwards, is called the 'Eurasian Rimland' and that it is the cornerstone of world domination. Spykman formulated Mackinder's theses of geopolitics as follows: "Who controls the Rimland rules Eurasia, who rules Eurasia controls the destinies of the world" (Gorgiladze 2009, 36).

Although the interests of Moscow and Beijing often strictly oppose each other, they still maintain a competitive and at the same time cooperative nature. Some scholars predict that a positive geopolitical rapprochement between Russia and China over the past few years could lead to the merging of the 'Silk Road Economic Belt' and the Eurasian Economic Union. According to some scholars, Chinese Eurasianism has not been observed yet. It is especially interesting to discuss the Chinese project in a theoretical context. It is thought that since the 2000s, both the domestic and foreign policy of the People's Republic of China has been based on the ethical-political doctrine of Confucius, as evidence of which might be considered the words of the Chinese President at the World Peace Forum in 2012. Confucius's basic views, postulates, and philosophical teachings develop the idea that only nonviolent and legal methods could establish peace and stability between the states. He argues that it is important to care for the well-being of not only his nation but also for the people of the world in general. According to Confucius, public order is based solely on the foundations of morality, and true, pure human relations are achieved through humanism, love, and respect.

Thus, one could argue that the traces of Confucianism in modern Chinese foreign policy, which develops the view that the main goal of the Belt and Road Initiative is to build a stable, harmonious economic world. The mentioned view ignores the principles of 'complex interdependence theory' formulated by Norman Angel in his 'Great Illusion' and developed by Joseph Nye and Robert Keohane (1989, 30-32) as an independent theory of international relations later on. The authors Nye and Keohane concluded that when the balance of economic power between the leading states increases, it might become more of a cause for confrontation than cooperation and cohabitation (Gvalia 2020). 
The other scholars go further and believe that China's strong economic prosperity in the $\mathrm{XXI}$ century is viewed in a negative prism, as it threatens not only the Eurasian continent but the entire civilized world. According to them, humanity is already facing the threat of Chinese imperialism, which opposes the hegemony of the United States and its universal values (Allison 2017). A clear example of Beijing's rise is its ambitious geopolitical project - the Belt and Road Initiative. The mentioned opinion is shared by the Turkish scientist A. Erol who believes that the implementation of the Belt and Road Initiative will "create a kind of hegemony of Chinese culture in the world" (Erol 2021).

\section{THE BELT AND ROAD INITIATIVE AND GEORGIA}

Georgia is a small country in the South Caucasus region. It is bounded to the West by the Black Sea, to the North by Russian Federation. To the South, the country shares borders with Turkey and Armenia and to the Southeast with Azerbaijan. The territory of Georgia is 69.700 square kilometers and the population of the country reaches about 3.78 million (Georgia country profile 2021). Georgia is situated at a strategically important crossroads between Western Asia and Eastern Europe, Black and Caspian Seas; it is positioned along the shortest routes between China and Europe. For this reason, throughout history, the country attracted considerable interest in the world's greatest Empires, such as the Russian, Roman, Ottoman, Mongol, and Persian Empires. Georgia was eventually annexed by the Russian Empire in the XIX century. Following the dissolution of the USSR, the country regained independence from the Soviet Union; however civil wars broke out in the country due to the two separatist regions of Abkhazia and South Ossetia. Following the dissolution of the Soviet Union, Georgia hosts two central pipelines: Baku-Tbilisi-Ceyhan oil and Baku-Tbilisi-Erzurum gas pipelines (Image 3) which run from the Caspian Sea to Europe, bypassing Georgian territory and transport Caspian hydrocarbon resources to Europe (Lomia 2017, 116). In the XXI century, Georgia once again attracted worldwide attention since it represents a critical transport node on the Belt and Road Initiative between China and Europe. 


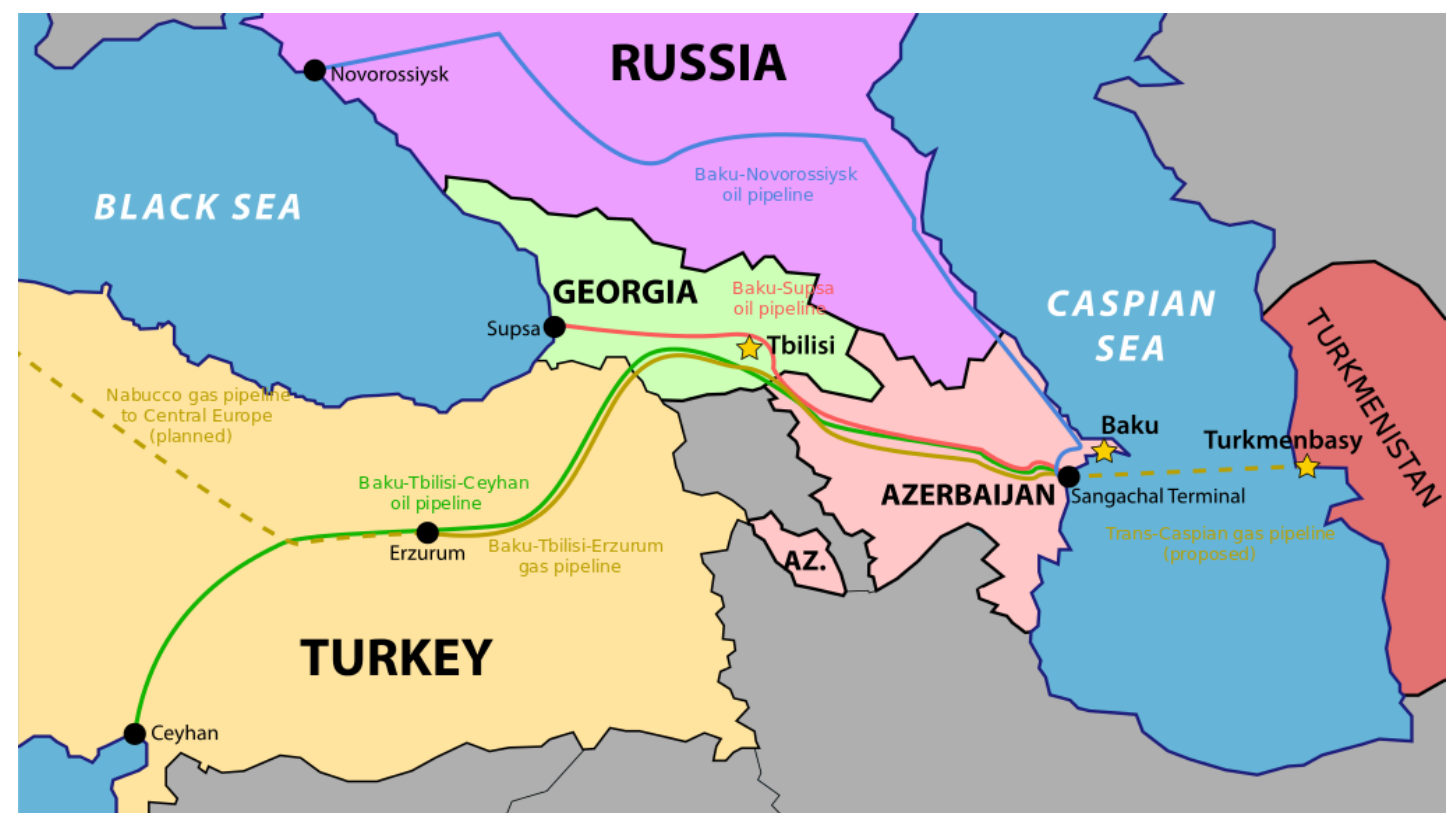

Image 3: South Caucasus - International Energy Crossroad (Source: The Foreign Policy Council 2021)

While the US remains Georgia's strongest and the most significant partner abroad Georgia has become a leading recipient of the US financial aid in Eurasia, which covers a wide range of priority areas in political, economic, military, and cultural fields. Georgia, in turn, has achieved significant progress in strengthening democratic values and principles in a very short time and aims to develop modern state institutions (Maisaia and Mikadze 2020, 134). There are strong grounds to believe that Georgia is the most democratic state in the Caucasus region whose international rankings, in terms of democratic development, are constantly increasing (Nikoleishvili and Kiknadze 2020, 129).

The People's Republic of China established diplomatic relations with Georgia on 9 June 1992 (Charaia and Anguridze 2020, 2). Bilateral ties have strengthened gradually since the beginning of the XXI century. Cooperation is mostly confined to the economic sphere, focusing on FDI and trade. Trade relations between the countries were established in 1992 as well (Larsen 2017, 5). According to Larsen (2017, 4), Georgia possesses three key features that make it attractive as a participant in China's Belt and Road initiative: "Free Trade Agreements (FTAs) with both the EU and China; an outlet to the Black Sea and overland links with Turkey, which offer platforms from which China can more efficiently conduct trade with the European Union; and a flexible position at the fulcrum of two regional formats, GUAM and AGT" (Larsen 2017, 4).

Georgia joined the Silk Road Initiative on 9 March 2015, when a new Silk Road Memorandum was signed between the People's Republic of China and Georgia (Charaia and Anguridze 2020, 5). This document led to the foundation for a new type of cooperation between China and Georgia, in the fields of infrastructure, logistics, energy, 
agriculture, and other areas, which significantly increased Chinese investment in Georgia. A large-scale Silk Road Forum is held in Tbilisi every two years and it includes the hundreds of leading economists, politicians and journalists, official representatives of the governments of Georgia, China, and other countries as well. The first forum was co-organized by the Prime Minister of Georgia and the People's Republic of China, and since then it has played a major role in the development and promotion of the Belt and Road Initiative in the Caucasus region (Charaia and Anguridze 2020, 7).

As highlighted by Mamradze "historical ancient 'Great Silk Road' passed through Georgia and the country, historically, has had friendly relations with ancient civilizations, including China" (Mamradze 2017). The relationship based on mutual trust and cooperation between the former President of Georgia Eduard Shevardnadze and thenPresident of China Deng Xiaoping deserves special attention as well. A visible illustration of this is the built of a hydroelectric power station in Georgia, with the support of China in Georgia during the most difficult period for Tbilisi (Mamradze 2017). Negotiations on Free Trade Agreement between China and Georgia began in September 2015 and entered an active phase in 2018. Georgia became the first country in the region to have a free trade agreement with both China and the European Union. Today, China is Georgia's leading trading partner, and Chinese investment in the country is significantly growing in recent years (Image 4).

Share of the top trading partners in total exports in January-July 2021 *

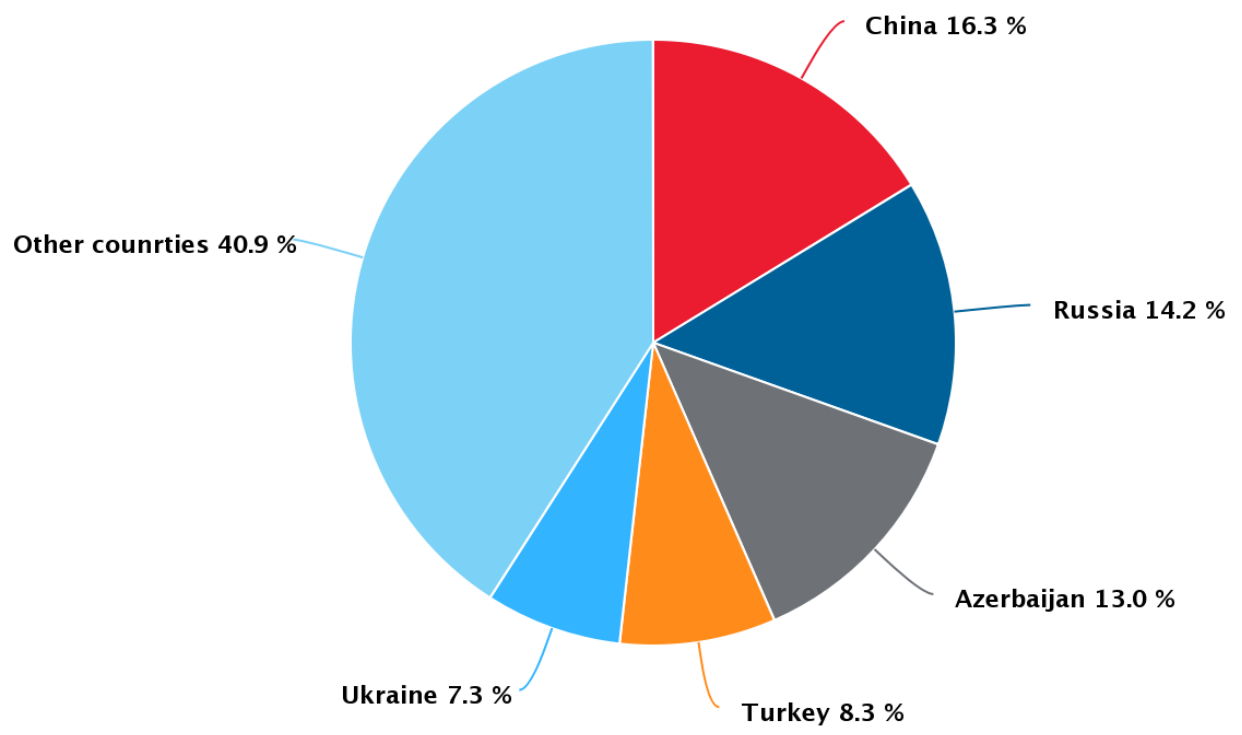

Image 4: Share of the Top Trading Partners in Total Exports in January-July 2021

(Source: National Statistics Office of Georgia) 
Although China is a relatively new market for Georgia, the demand for Georgian products in the country is growing monthly. Georgian producers import wine, mineral drinks, nuts, fish and seafood, fruits, vegetables, honey, tea, plastic products, etc., to China. Georgian wine is especially popular in the Chinese market. Since 2018, more than 30 Chinese companies have actively been working with the Georgian side to ensure a high degree of credibility (Charaia and Anguridze 2020, 20-21).

In this prism, the implementation of the 'Anaklia Deepwater Port' project is especially important, which is a vital factor in ensuring the country's security and credibility in an international arena. According to the Chinese project, the 20.5-meterlong deep-water port of Anaklia will be used for transiting goods from China to the European market (Aroshidze 2018).

\section{CONCLUSION}

Following the initiation of Xi Jinping's Belt and Road Initiative, China has become a center of global influence. It received the status of great power and became an important factor in today's world order. In this way, China's rise to the way of global hegemony 'has started'. The Belt and Road Initiative aims to deepen the links between China and Europe by expanding the transport network through railways and ports. This will also lead to a significant reduction in transportation costs. Numerous studies have shown that the 'revival' of the historic 'Silk Road' will significantly increase the South Caucasus-China relations and bring economic benefits for both sides.

Today, China is Georgia's third-largest economic partner. Trade and economic turnover between Georgia and China exceed one billion dollars. With the involvement of Georgia in the Chinese project, the country will receive the greatest economic benefits, first of all by attracting investments from China. This, in turn, may become a unique opportunity for the country. Thus, the Georgian government should make every effort to establish closer relations with China. Georgian-Chinese cooperation is especially beneficial for Tbilisi, not only in an economic but also in a political context. The People's Republic of China hugely supports the territorial integrity and sovereignty of Georgia and does not recognize Abkhazia and South Ossetia as independent states.

Therefore, the realization of the Belt and Road Initiative gives Georgia another unique opportunity to become a hub connecting China and the EU and enjoy the economic benefits gained through this. Georgia has already signed a free trade agreement with China and a 'deep and comprehensive free trade agreement' with the European Union, which is a significant achievement for the country. The project is also of great importance in the geopolitical context. The construction of the 'Anaklia Sea project' of Georgia has further worsened the US-China relations as well, which in turn, has already been illustrated in the economic war between Washington and Beijing. 
The US is the main strategic partner of Georgia and Georgia has to first and utmost maintained the positive dynamic of the Georgian-American relations. It is significant to note that Georgia's pro-Western orientation has been defined from the very first day of its independence and even though there have been several changes of regime, the country has never altered its long-defined strategic choice. Former Georgian Presidents Zviad Gamsakhurdia and Eduard Shevardnadze took the first steps towards Georgia's pro-Western course, which has been strengthened by Mikheil Saakashvili. Whilst Bidzina Ivanishvili's pro-Russian orientation, at first, raised concerns in Georgian political elites that the US-Georgian relations would undergo certain negative changes and Russian-Georgian relations would improve instead, nevertheless, the Georgian government has continued moving in the right direction and has further deepened the partnership with the United States. Thus, the Georgian government has to carry out a constructive, consistent, and reasonable foreign policy with China not to irritate the US.

On the other hand, Georgia's involvement in the Chinese project will contribute to the further socio-economic development of the country and economically strong Georgia is in the direct interests of the US as well. As for Russia, Moscow seeks to maintain its influence in the Central and South Caucasus region. However, since the 'Central Asia-West Asia' economic corridor does not run directly into Russian territory, successful implementation of the Chinese project is not in Moscow's interests. 


\section{REFERENCES}

1. Allison, G. (2017). Destined for War: Can America and China escape Thucydides's trap. Houghton Mifflin Harcount.

2. Amborn, M. (2010). Public Meetings. DOTSC - Training Presentation.

3. Arent, R. (2009, / /). https://www.press.umich.edu. Retrieved June 20, 2021, from https://www.press.umich.edu/pdf/9780472033577-ch1.pdf

4. Aroshidze, P. (2018). China's mew geostrategy and Georgia's perspectives. 37.

5. Asociacioni i Komunave të Kosovës. (2008). Doracak i Qeverisjes Lokale. Prishtina: OSCE - Mission in Kosovo.

6. Amazing Iran. (2021). Retrieved June 20, 2021, from https://www.amazingiran.com/silk-road/

7. Bakija, J. (2017). Doracak Praktik për Anëtarë të Kuvendit Komunal - Përfaqësues Proaktiv dhe Efektiv. Prishtina: D+ \& KAS.

8. Charaia, V., \& Anguridze, O. (2020). China factor in Georgian economy. 7.

9. Chitadze, N. (2021, April). Expert Interview. Recorded by the author.

10. Council of Europe. (2021, / /). https://www.coe.int. Retrieved June 10, 2021, from https://www.coe.int/en/web/congress/european-charter-of-local-selfgovernment

11. Erol, A. (2021). Interview (Recorded by the author in April 2007).

12. Etzioni, A. (2015). Community. In J. W. Sons, The Encyclopedia of Political Thought (pp. 4-5). /: Published 2015 by John Wiley \& Sons, Ltd.

13. Fred, L. C. (2010). Communication: The process, Barriers, and Improving Effectiveness. SCHOOLING VOLUME 1, Volume 1, 2.

14. Georgia, country profile. (2021). Retrieved from https://www.nationsonline.org/oneworld/georgia.htm

15. Gorgiladze, I. (2009). The basis of Geopolitics. 36.

16. Gvalia, G. (2020). The future of US-China relations: Conflict or partnership.

17. INOGATE. (2020). The regional energy cooperation program between the European Union and 11 partner countries in Eastern Europe.

18. Jemie, B. (2014, January 17). https://www.thoughtexchange.com. Retrieved July 30, 2021, from https://www.thoughtexchange.com: https://www.thoughtexchange.com/blog/5-reasons-to-include-community-indecision-making/

19. Joe, O. (2007, January /). https://icma.org. Retrieved July 20, 2021, from https://icma.org: https://icma.org/sites/default/files/6270_.pdf

20. Kamberi \& Vejseli. (2019/2020). Hulumtim i perceptimeve të komunitetit lidhur me Identiteti kulturor i shqiptarëve të Maqedonisë së Veriut përball diversiteteve prej 1990-deri me sot dhe Zhvillimi i komunitetit dhe qeverisja lokale - studim krahasues i komunave të rajonit të Prishtinës. Maqedoni Veriore: Shkup, Tetovë, 
Gostivar, Kërçovë dhe Dibër; Kosovë: Prishtinë, Obiliq, Fushë Kosovë, Drenas dhe Graçanicë.: Authors.

21. Kamberi, F. (2018). Participation of the Community in the Decision-Making Process - Case the Municipality of Pristina. Path of Science, Vol 4 (8), 5001-5012.

22. Karaganov, S. (2016). From East to West, or Greater Eurasia. Russia is actively gaining a foothold in the growing Asian markets.

23. Keohane, R., \& Joseph, N. (1989). Power and independence. Longman 2nd Ed.

24. Kiknadze, T. (2007). Terrorism as a social reality. NATO SECURITY THROUGH THROUGH SCIENCE SERIES E HUMAN AND SOCIETAL DYNAMICS, 22(2007):51.

25. Krasniqi, B. (2004). Financial Barriers to SME Growth: Empirical evidence from Kosova. 3rd International Conference "International Business in Transition" (pp. 911). Riga: Stockholm School of Economics.

26. Kukovič, S. (2005). New Forms of Participatory Democracy at Local Level: eCitizens? Journal of Comparative Politics, 8 (2), 33-34.

27. Larsen, J. (2017). Georgia-China Relations: The Geopolitics of the Belt and Road. Policy Paper, Georgian Institute of Politics.

28. Law N0. 03/L-040 on Local Self Government. (2008, February 20). https://gzk.rksgov.net. Retrieved July 10, 2021, from https://gzk.rks-

gov.net/ActDetail.aspx?ActID $=2530$

29. Ligji për Vetëqeverisje Lokale. (2020, / /). http://mls.gov.mk. Retrieved July 10, 2021, from http://mls.gov.mk/images/laws/Ligji\%20i\%20veteqeverisjes\%20lokale.pdf

30. Lomia, E. . (2020). THE EVALUATION OF RUSSIA'S FOREIGN POLICY TOWARDS GEORGIA FOLLOWING THE 'ROSE REVOLUTION. Journal of Liberty and International Affairs, 6(1), 112-128. Retrieved from https://ejlia.com/index.php/jlia/article/view/178

31. Maisaia, V. (2005). The New Face and Reality of Terrorism in the 21 st Century: Militant Religious Movements. Insight Turkey, 147-156.

32. Maisaia, V., \& Khanjaliashvili, E. (2020). Georgia's Security Environment And Combating Terrorism-New Challenges And Threat In 21st Century. Security Science Journal, 1(1), 113-121.

33. Maisaia, V., \& Mikadze, V. (2020). THE EU DEFENCE POLICY AND CAUCASUSCASPIAN REGIONAL SECURITY-TRACING FROM CRISIS MANAGEMENT TILL STABILITY: GEORGIA'S CASE. Ante Portas.

34. Mamradze, P. (2017, July 7). China project OBOR (One Belt- One Road) and the perspective of Georgian-Chinese relations. Tbilisi: Center for global studies. Retrieved August 10, 2021, from http://globalresearch.ge/research/petremamradze-china.html

35. Marshall, G. \&. (2009). A dictionary of sociology. Oxford University Press. 
36. McNair, B. (2011). An Introduction to Political Communication (Fifth edition ed.). London and New York: Routledge.

37. Ndreu, A. (2016). The Definition and Importance of Local Governance. Social and Natural Sciences Journal, Volume 10 (Issue 1), 5.

38. Nikoleishvili, L., \& Kiknadze, T. (2020). Peculiarities Of The Phenomenon Of Political Leadership In Post-Soviet Georgia. International Journal of Innovative Technologies in Social Science, 6 (27).

39. Nurgaliyeva, L. (2016). Kazakhstan's economic soft balancing vis-a-vis Russia: From the Eurasian Union to the economic cooperation with Turkey. (7 (1)), 93-96.

40. Papava, V. (2008). On the role of the "Caucasian Tandem" in GUAM. Central Asia and the Caucasus $(3-4 \mathrm{~m}), 47$.

41. Papava, V. (2008). On the role of the "Caucasian Tandem" in GUAM. Central Asia and the Caucasus, 3-4 (51-52), 47.

42. Papava, V. (2017). One belt - one road initiative and Georgia. 4.

43. Pollozhani, Bajram \& Dobjani, Ermir \& Stavileci, Esat \& Salihu, Lazim. (2010). E drejta Administrative - Aspekte krahasuese. Tetovë: Asdreni.

44. Sarker, M., Hossin, M. A., Yin, X., \& Sarker, M. K. (2018). One belt one road initiative of China: Implication for future of global development. Modern Economy, 9 (4), 623-638.

45. Schutte, D. W. (2016). Community Development and Community Participation: A Conceptual Revisit. Affiliation: the Cape Peninsula University of Technology, Department of Environmental and Occupational StudiesVersion: 01State: In Progress, 9.

46. Selimi, F. (2008). Qeverisja Vendore - Shqyrtime krahasimtare. Prishtinë: Vatra.

47. Shasivari, J. (2020). E drejta kushtetuese (Second Edition ed.). Shkup: Furkan ISM.

48. SNGWOFI. (2019, February /). Retrieved June 20, 2021, from https://www.sngwofi.org/country-profiles/Fiche\%20NORTH\%20MACEDONIA.pdf

49. Standard Chartered. (2021). Retrieved June 20, 2021, from https://www.sc.com/en/feature/one-masterplan-six-corridors/

50. The Foreign Policy Council. (2021). Retrieved 12 September 2021, https://foreignpolicycouncil.com/2018/11/12/south-caucasus-internationalenergy-crossroad/

51. Taylor, G. S. (2009, April /). https://core.ac.uk. Retrieved July 20, 2021, from https://core.ac.uk/download/pdf/147130639.pdf

52. TRACECA. (2019-2020). Transport corridor Europe Caucasus Asia. Asia Regional Integration Center.

53. Vekua, K. (2018). The EU and the One Belt - One Road initiative from a Peace Science Perspective. 3-4. 